\title{
Editorial: Financing for Development: The Progress Money Cannot Buy
}

\author{
Stefano Prato ${ }^{1}$
}

Published online: 12 June 2017

(C) Society for International Development 2017

The Third International Conference on Financing for Development (FfD), which took place in Addis Ababa in July 2015, generated significant frustration among all those progressive thinkers, activists and policymakers that had hoped it could advance the democratization of economic governance and the removal of the structural obstacles that continue to hinder the socio-economic transformation of developing countries and their increasingly equal participation in the global economy. On the contrary and despite the fanfare of the 2030 Agenda for Sustainable Development (United Nations 2015a), the conference outcomes were marked by significant regressions as well as problematic developments, such as the pervasive narrative in favour of the unchecked promotion of the corporate sector through blended finance and public-private partnerships (PPPs).

However, also thanks to the untiring effort of civil society, the Addis Ababa Action Agenda (AAAA) (United Nations 2015b), which also helps contextualizing and complementing the means of the implementation (MoI) of the 2030 Agenda, institutionalized a follow-up process, centred around an annual Forum to be held under the auspices of the United Nations Economic and Social Council (ECOSOC). This annual event could open a small window of opportunity to advance a progressive normative agenda for financing sustainable development. However, there is an urgent need to articulate new visions, strategies and proposals and infuse them in the process. This Journal issue aims to provide a contribution in this direction.

Stefano Prato

stefanop@sidint.org

Society for International Development, Rome, Italy
While civil society denounced the adequacy of the AAAA to match the ambition of sustainable development, the combined MoI/AAAA framework still offers useful entry points to advance a progressive agenda. However, two main challenges undermine implementation: the refusal of developed countries to engage in any meaningful democratization of global economic governance and the pervasive private sector bias.

\section{The Apparently-Forgotten Global Dimensions of the 2030 Agenda}

The initial process to pursue the 2030 Agenda has witnessed a very strong push for national implementation. While such a national focus is necessary and welcome, the term 'national' tends to be used primarily to refer to developing countries and the global dimensions of the agenda are constantly underplayed. Developed countries are therefore successfully deflecting attention from their responsibilities, while placing the spotlight on developing countries' national progress. Meaningful discussion on the 'four big elephants' of the global system, namely trade, finance, climate and human mobility, remains peripheral, if not completely unaddressed, in the implementation and review process, despite the continued evidence that no real and lasting progress can be made without realigning the governance of these four major shapers of today's globalization to the imperatives of human rights and sustainable development. Unfortunately, the first two editions of the ECOSOC Forum on Financing for Development (FfD) Follow-up confirmed the unwillingness of developed countries to address these global issues within the United Nations context and reaffirmed their intent to continue to ring-fence the institutions they control. Interestingly, the 
'champions of democracy' seem to refuse the democratization of global economic governance. At the same time, the discussion on MoI and FfD continues to be dominated by a pervasive private sector bias, which, under the worrying slogan of 'making the business case for sustainable development', identifies in the unlocking of private finance and action the fundamental key to SDG implementation.

\section{Policy Incoherence and Global Economic Governance}

Rather than resource provision, the first real challenge in advancing the FfD agenda can therefore be seen in the resistance to the democratic redesign of global economic governance. Progress on international tax cooperation, debt sustainability, equitable multilateral trade systems and alignment of international financial institutions to sustainable development, either requires new universal and democratic institutions and frameworks or the democratization of existing ones. Notable examples are developing countries' calls for a global intergovernmental tax body and for an effective international debt workout mechanism. Unfortunately, the call for democratization meets the obstinate rejection of developed countries, that rather continue to build and strengthen their own institutions (e.g. the OECD) or those they unevenly control (e.g. Bretton Woods Institutions).

Not only does this represent an obstacle to progress, but it also continues to fuel significant policy incoherence, despite the fact that policy coherence with human rights and sustainable development is one of the critical pillars to advance the pursuit of the 2030 Agenda. In this respect, the United States' reservation on the intergovernmental outcome of the 2017 ECOSOC Forum on FfD Follow-up (United Nations 2017) is therefore emblematic: '(...) the United States disassociates from the sentence in Paragraph 20 that calls on all regional and global organizations and institutions to consider the SDGs as they develop their strategies, policies, and practices' (United States Mission to the United Nations 2017). This statement obviously raises the immediateness of the challenges to global economic governance which are posed by the shifting geopolitical context and the resurgence of assertive power politics, as these generate profound consequences on consensus-based processes where 'minus-one' or 'minussome' arrangements cannot be pursued. Both the follow-up and review of the 2030 Agenda and the FfD follow-up process fall in this category.

The other victim of the incapacity to advance the democratization of global economic governance is the aspiration to address systemic issues, one of the characterizing features of the Monterrey Consensus on FfD.
Inadequate financial market reforms, continued inability to address the financial drivers of commodity price volatility, new challenges to debt sustainability also promoted by the financialization of infrastructure, and the resistance to use mechanisms such as Special Drawing Rights to strengthen financial safety nets, all contribute to increasing the systemic risks of the current pattern of globalization, not to mention the continued resistance by some to fully recognize the systemic nature of the climate risk. Unfortunately, the FfD follow-up process has not yet proved to be able to provide the space for both foresight and preventive action to indemnify the quest for sustainable development against the next systemic crisis.

As developing countries are pressured to advance national implementation of the 2030 Agenda, systemic structural obstacles continue to limit the policy and fiscal space to advance their development actions and shift the centre of gravity of their economies in favour of the domestic market. This situation continues to relegate many countries - particularly many African countries - to conditions of commodity-dependence and unacceptably low levels of economic diversification, given their inequitable positioning in the global organization of production. Another inacceptable example of policy incoherence is represented by the ongoing attempts to establish normative hierarchies between investors' rights and human rights through trade and investment agreements, further limiting the development policy space of developing countries.

\section{Private Sector Bias Versus the Necessary Realignment of the Business Model}

The second challenge to the meaningful advancement of the FfD agenda is provided by the pervasive narrative related to the private sector. Here, the main drivers are sometimes unclear. Many are quick to point the finger towards attempts by private, often large corporate actors to capture the public space. While this might be the case, the private sector bias of many governmental representatives is often disheartening and exposes a mindset of abdication of the State's responsibilities in the face of challenges the state seems to feel inadequate or powerless to confront. At times, the State's desire to cede the public sphere to the private sector seems larger than the desire of the private sector to seize it. And this creates a very weak negotiation context where the attempts to seduce the private sector tend to result in the actual seduction of the State.

In this context, the private sector question is often wrongly posed. It is probably true that the engagement of the private sector holds many of the keys to the success in the implementation of the 2030 Agenda. But the premise 
needs to be the recognition that the current economic frameworks are responsible for unacceptable levels of exploitation of people, communities and natural resources, are damaging our ecosystems and continue to reproduce a global neo-colonial division of labour that relegates many developing countries to the lower end of the global organization of production. Furthermore, these frameworks thrive on patriarchal structures and continue to exploit women's social reproduction roles. This has led to an understanding of production and productivity that defines as external most of the social, environmental and political imperatives of sustainable development. The fundamental role of the State is that of redrawing the lines the generate today's gap between what is legal and what is sustainable. Expecting that this gap would be filled by voluntary initiatives of the private sector is an abdication of State's responsibility to regulate in the public interest. It is also a fairy tale.

However, regulatory initiatives are no easy tasks in today's globalized economy and require high degrees of concerted global action to prevent harmful 'races to the bottom'. In this context, the governance question resurfaces, considering that the rankings and implicit policy prescriptions of the World Bank's Doing Business and Enabling the Business of Agriculture (EBA) reports are driving pro-private sector de-regulations across the world. Against this background, the first immediate step in reclaiming the regulatory role of the state remains the process initiated by the Human Rights Council though the establishment of the open-ended intergovernmental working group on transnational corporations and other business enterprises with respect to human rights, whose mandate is to elaborate an international legally binding instrument to regulate, in international human rights law, the activities of transnational corporations and other business enterprises.

But regulation is not the only available instrument. The use of fiscal instruments to redress the relative pricing of the factors of production, for instance by decreasing or removing taxes on labour while increasing taxation on the use natural resources, may lead innovation in different directions than today's constant search to minimize the labour cost factor. Unfortunately, very limited policy discussions are held to explore these options. On the contrary, normative and fiscal incentives are often targeted precisely at the wrong-doers, for instance by de-taxing productive transitions to more sustainable production patterns, therefore socializing the cost of adjustment rather than obliging it to be borne within the private sector itself. Interestingly, limited incentive schemes exist to support alternative economic models that fully internalize social, environmental and political dimensions, such as agroecology, circular economies and social solidarity economies, among others.

\section{The Public-Private Conundrum}

Beyond the realignment of the business model with sustainable development, a second critical dimension of the private sector bias is related to the call, sometimes plea, to the private sector to partner with the public sector in the delivery of public goods and services. The term publicprivate partnership (PPP) is therefore used to both describe this general phenomenon and indicate particular contractual arrangements, which is what the PPP acronym tends to more specifically refer to.

Over the past years, several research initiatives led by civil society organizations and even international organizations have analyzed PPPs, raising concrete evidence of their shortcomings (EURODAD 2015). Several reports highlighted how PPPs tend to change the nature of public services with very limited evidence of greater efficiency, significantly increase the public cost if compared to public procurement, offer higher risks than public investments that are almost entirely socialized, and undermine democratic accountability. When applied to large infrastructural projects, they may also contribute to generating unsustainable debt levels by escaping public accountability and provide easy avenues for the financialization of these investments.

However, four key dimensions of this discourse help to problematize and contextualize this push for public-private partnerships. The first one is related to the emerging confusion on what is public and what is private. The oftenunqualified call to mobilize private finance and engage the private sector is not backed by any clear understanding of what is private, what should remain public and is best delivered by the public sector, and what is public but can be delivered by the private sector. Clearly, these distinctions are highly context-sensitive and different answers can be provided in different national situations, but no discussion seems to be currently framed in the firm recognition that there are public goods and services which are the distinct competence of the public sector.

The second dimension is related to the fact that boundaries between the public and the private are not fixed and private ownership is increasing shifting from physical to financial capital. Public partnerships with the private sector should therefore be located in the continued processes of commodification and financialization that are often aggressively promoted by the current pattern of economic globalization. Commodification is the process of extending the range of goods and services which are produced and commercialized by the private sector and traded within markets. It continuously erodes the concepts of public goods and human rights, as exposed by the commodification of food, water and health. It is therefore not 
by chance that the 2030 Agenda does not frame food, water and health as fundamental human rights, but rather addresses these as needs to be met, further opening the way for private provision. Beyond social services, the next frontier of commodification is knowledge, as widely exposed by the corporatization of seeds and genetic resources. Financialization, on the other hand, is a process that separates the ownership of physical capital from the ownership of financial capital, and progressively shifts the centre of gravity of the economy away from production and consumption in favour of financial ownership, thereby increasing the size and importance of the financial sector in the management of the economy. The net effect of these two drivers is the increasing power distance between people and economic ownership and decision-making, rendering the reshaping of the economy to serve the needs of the people dramatically challenging. Beyond short-term consideration on effectiveness, transparency and financial efficiency, one of the most profound concerns about publicprivate partnerships is therefore their significant contribution to commodification and financialization and the consequent squeezing of the capacity of the State to regulate the economy in the public interest.

The third dimension is related to the widening of the modalities of public-private interaction, with high rates of innovation in the interaction between the public and the private. This evolving reality poses new challenges to those policymakers that want to establish guidelines and safeguards to protect the public interest within PPPs, as called upon by the AAAA. While vigorous campaigning by civil society against harmful PPPs is essential along with advocacy to establish proper guidelines to protect the public interest, these policies may quickly become obsolete if the modalities of public-private interaction evolve to new forms that may not be covered by these safeguards. This led the Civil Society FfD Group to forge the term 'publicprivate interfaces' (PPIs) to refer to this broader phenomenon and to initiate a global survey to identify and cluster these new modalities to offer policymakers a more comprehensive analytical context to frame their safeguarding interventions.

The fourth and last dimension is related to the increasing participation of the private sector in public policy spaces, often translating into outright corporate capture. The underlying premise is the belief that there is a significant overlap between public and private interests, despite the glaring evidence to the contrary. This misunderstanding calls for prompt action to defend the integrity and restore the rights-holder centeredness of public policy spaces against their progressive 'stakeholderization'. This implies the prompt establishment of robust safeguards against conflicts of interest, which should range from excluding private financing, protecting the integrity of the policy process and ensuring the trustworthiness of the research and evidence that informs and supports policymaking.

\section{Conclusions}

The resistance to the democratization of global economic governance and the pervasive private sector bias represent significant, if not unsurmountable, obstacles to the advancement of a progressive FfD agenda and the pursuit of the SDGs. Rather than means of implementation, the international community is confronted with 'means of appropriation' of the development aspirations of developing countries and their communities to maintain an outdated, untenable, fragile and undemocratic economic order. Indeed, real progress in financing for development requires something money cannot buy.

\section{References}

EURODAD. 2015. What lies beneath? A critical assessment of PPPs and their impact on sustainable development. http://www. eurodad.org/files/pdf/55cb59060d9d4.pdf.

United Nations. 2015a. Transforming our world: The 2030 Agenda for Sustainable Development. http://www.un.org/ga/search/ view_doc.asp?symbol=A/RES/70/1\&Lang=E; http://www.un. org/esa/ffd/wp-content/uploads/2015/08/AAAA_Outcome.pdf.

United Nations. 2015b. Addis Ababa Action Agenda of the third international conference on financing for development.

United Nations. 2017. Inter-governmentally agreed conclusions and recommendations of the ECOSOC Forum on Financing for Development Follow-up. http://www.un.org/esa/ffd/ffdforum/ wp-content/uploads/sites/3/2017/05/E-FFDF-2017-L.1_DraftOutcome.pdf.

United States Mission to the United Nations. 2017. Explanation of position on the Financing for Development outcome document, delivered by Stefanie Amadeo, U.S. Deputy Representative to ECOSOC, on May 23, 2017. https://usun.state.gov/remarks/ 7812. 